\title{
THE POSSIBILITIES OF SUSTAINABLE LAND USE FORMATION IN UKRAINE
}

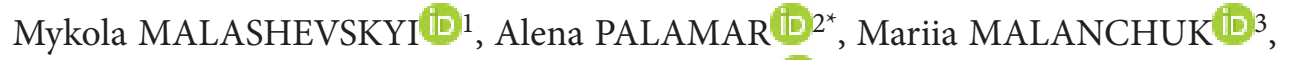 \\ Olena BUGAIENKO 4 \\ ${ }^{1}$ Department of Land Management and Cadastre, Sumy National Agrarian University, \\ Gerasim Kondratiev Str. 160, 40000 Sumy, Ukraine \\ ${ }^{2}$ Department of Geodesy, Kryvyi Rih National University, Vitaly Matusevich Str. 11, 50027 Kryvyi Rih, Ukraine \\ ${ }^{3}$ Department of Cadastre of Territory, Lviv Polytechnic National University, Bandera Str. 12, 79013 Lviv, Ukraine \\ ${ }^{4}$ Department of Land Management and Cadastre, Kyiv National University of Construction and Architecture, \\ Povitroflotsky Ave. 31, 03680 Kyiv, Ukraine
}

Received 8 January 2019; accepted 22 November 2019

\begin{abstract}
The tendencies of the land fund change during the last years are considered. An analysis of a number of normative documents was made to highlight the main problems in modern land use. A number of problems in the sphere of land relations during the period of land reform are listed. The systematic deforestation of protective forest stands, violation of the regime of land use within the boundaries of water protection zones and coastal protective bands is observed. In the article, an acute need to implement measures for the use and protection of lands with a view to meeting the set tasks within the territories, which are subjected to significant anthropogenic load as a result of population accumulation and high intensity of land use is highlighted. The need for comprehensive measures to develop and implement technical solutions for the rationalization of land use and land protection is argued in the article. The evaluation of the distribution of agricultural enterprises by the average area of agricultural and the share of the total area of agricultural land in Ukraine, which they occupy is presented. The dynamics of changes in the areas of agricultural land and arable land in their composition, as well as pastures, hayfields, deposits, and perennial plantations is investigated.
\end{abstract}

Keywords: land use, land management, protection of land, agriculture.

\section{Introduction}

Earth is the basis of human existence, which determines its important role in the process of social and economic development of society. As the basis of the ecosystem, the tool and the object of production, the object of ownership, it is the basis of sustainable development, a condition for social progress and human well-being. The political and economic changes that began in the countries of Central and Eastern Europe in the early '90s of the 20th century covered the sphere of land use. During the reform, the former land system was changed, new principles for the development of land relations were established. History does not know examples when within a decade the landed property was completely changed in this way. Today in Ukraine there are 22.2 million landowners, 3.2 million land users. In Ukraine, about 7 million citizens have received land certificates certifying the ownership of land shares, of which about 6.8 million peasants have already received state acts on the right of private ownership of land. At the same time, 11 million citizens privatized the land: for the construction and maintenance of residential buildings, outbuildings, gardening, cottage and garage construction, etc. In the process of reforming of land relations, 16,100 new types of agroformations were created on the basis of 11,300 collective agricultural enterprises.

The practice of the member countries of the European Union has proved that a developed and wellinstitutionalized land market ensures the distribution of land ownership in a way that achieves a rational use of land resources. The process study results of the land relations transformation in Bulgaria, Estonia, Latvia, Lithuania, Poland, and Romania made it possible to identify the main elements of the formation of a fullfledged agricultural land market, namely: cadastre,

${ }^{*}$ Corresponding author. E-mail: palamar1alena@gmail.com 
specialized land institutions, a market mechanism for land evaluation, leasing relations and state regulation.

In the countries of the European Union, there is no absolutely free land market, unlimited right of land private ownership and uncontrolled operations with its purchase and sale. In Bulgaria, Estonia, Poland, Lithuania, and Romania, in addition to economic methods of regulating land relations and the land market, administrative and legal levers are increasingly being used. Government bodies oblige landowners to carry out reclamation and protection measures in accordance with developed and controlled plans, confiscate lands, which are used inefficiently and transfer them at auction. Land Experience in the European Union showed that only functioning state with a high level of cooperation between all branches of government and developed market institutions is able to guarantee property rights, acquired in the process of concluding market transactions.

The formation of a rational landowning and land use systems in Ukraine largely depends on the variable socioeconomic conditions. With gaining of independence, the country received new forms of land management, the acute need for spatial ordering of the territories became an appropriate regularity. With the development

January 1,1990

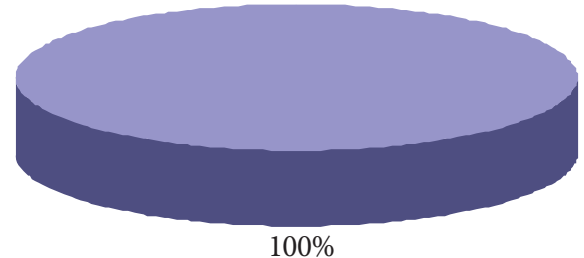

January 1,2002

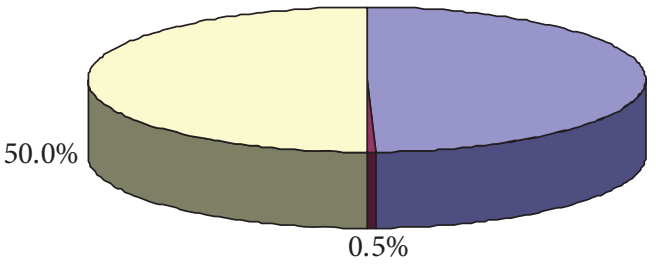

January 1,2014

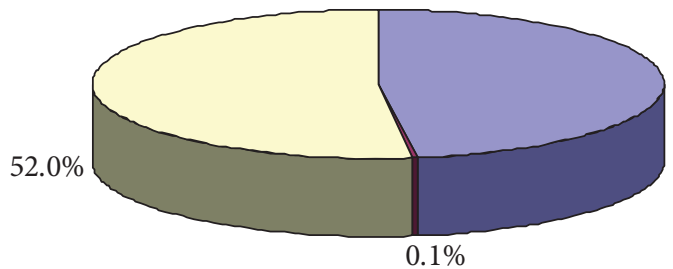

- Lands of state ownership

口 Lands of private ownership of various forms of land management and land sharing, the spatial distribution of land use, the qualitative and quantitative composition of the land, often do not meet the requirements for effective land use. The basic principles of land use regulation and the current landowning and land use system in Ukraine are formed under the influence of land reform. In particular, the adoption of a number of normative and legal acts initiate the beginning of significant changes in the spatial organization of lands and the principles of their use, which are not always positive.

The current system for planning the development of the territory in Ukraine is not sufficiently formed and balanced and does not provide a positive result in achieving high economic efficiency and environmental safety in land use.

The purpose of the study is to determine the possibilities of improving the methodology for calculating the size of agricultural land in the process of land exchange by reflecting the main factors of influence in contemporary socio-economic conditions.

For land tenure and use within settlements, where with a significant pace of construction, the differentiation of private, state and municipal property rights and other special features, the spatial organization of lands as part

anuary 1, 1996

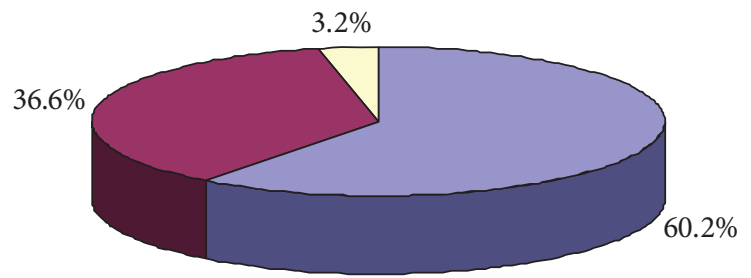

January 1, 2008

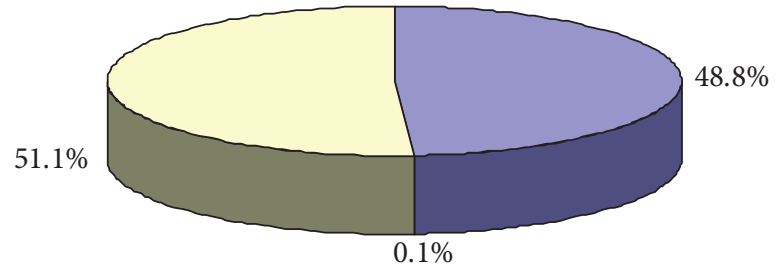

January 1, 2016

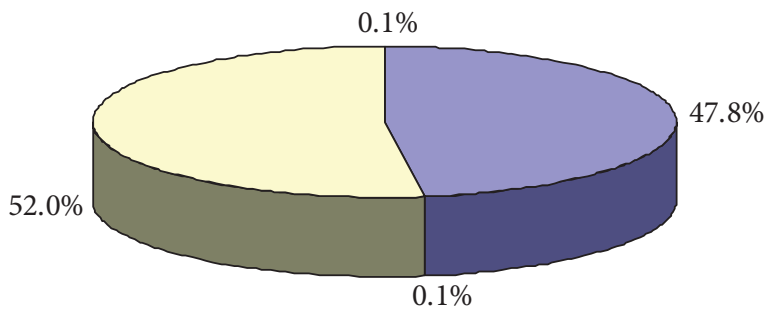

- Lands of collective ownership

- Lands of communal ownership

Figure 1. The land fund of Ukraine by forms of ownership in accordance with the data of the StateGeocadastre, \% of the total area 
of the reorganization and streamlining is the determining component of sustainable land development. Therefore, in the current conditions of land relations reforming, the issue of lands spatial ordering implementing with the aim of achieving more effective diversified use is acute.

In this regard, it is necessary to further study the mechanisms of land redistribution, among which, the exchange is the basic, taking into account the objective spatial limitation and the crucial role of land in production and placement. Particular attention should be paid to the possibilities and prospects for a land exchange in light of the main tasks of modern land management.

\section{Materials and methods}

On examination of the current state, it is advisable to highlight the Land Code of Ukrainian SSR of December 18, 1990, No. 561-XII (expired on January 1, 2002), Resolution of the Verkhovna Rada "On Land Reform" of December 18, 1990 No. 563-XII (Verkhovna Rada of the USSR, 1991), "On the acceleration of land reform and land privatization" of March 13, 1992 № 2200-XII (Verkhovna Rada of Ukraine, 1992), the Land Code of Ukraine of January 1, 2002 (Verkhovna Rada of Ukraine, 2002), the provisions of which became the basis for the development of various forms of ownership of land. Since the borders of Ukraine have long been defined, only forms of management can change. Let's consider the tendencies of the land fund change during the last years (Figure 1). Accordingly, the Land Code of Ukraine of January 1, 2002 stipulated the norms of free privatization of lands of various categories, the process of agricultural land division into shares, which is additionally regulated by the provisions of the Law of Ukraine "On farming" of June 19, 2003 No. 973-I V (Verkhovna Rada of Ukraine, 2014), Decree of the President of Ukraine "On the procedure for dividing lands transferred to collective ownership of agricultural enterprises and organizations" of 08.08.1995 No. 720/95 (President of Ukraine, 1995), Law of Ukraine "On the procedure for the allocation at the site of land plots to the owners of land shares" dated 06/05/2003 No. 899-IV (Verkhovna Rada of Ukraine, 2003) and other regulatory legal acts.

Currently, the average size of private land is about 2.46 hectares, the state -7.47 hectares, communal 1.08 hectares (Nizalov et al., 2016). Thus, the number of landowners and land users has also changed. About 45 thousand agricultural enterprises, according to the State Statistics Service, use 21.5 million lands. According to current analytical studies (Repin, 2016), only about 17 million, both rural and urban households use $38.4 \%$ of agricultural land. At the same time, about $10 \%$ of agricultural enterprises use the area of land up to 5 hectares (Figures 2,3 ). The total area of agricultural land is $21,529.8$ thousand hectares

The land redistribution, which was aimed at the achievement of equal development of various forms of land management, the formation of a multi-structure

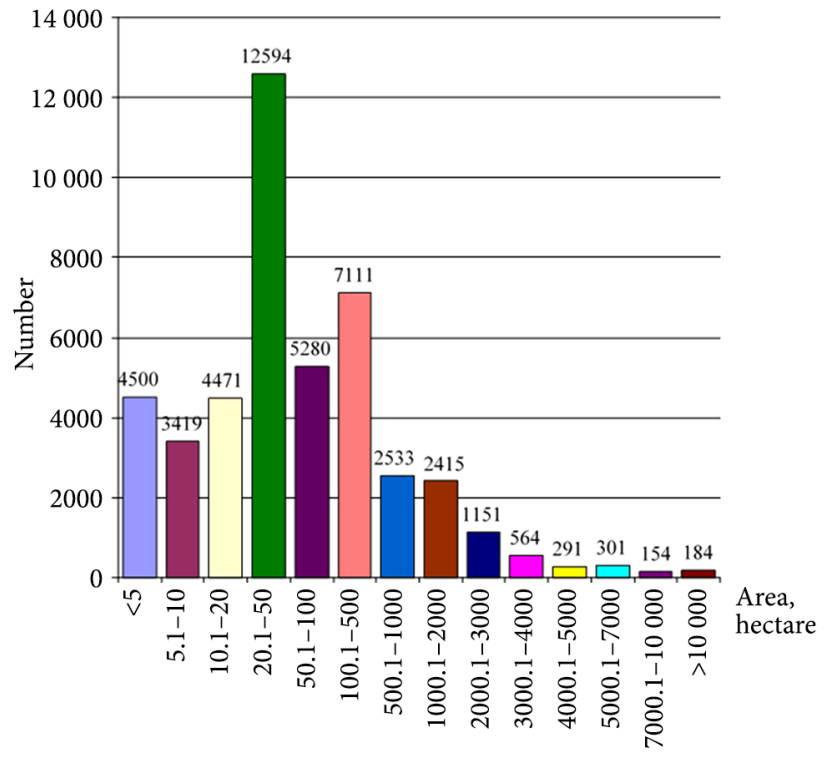

Figure 2. Distribution of agricultural enterprises by the average area of agricultural land

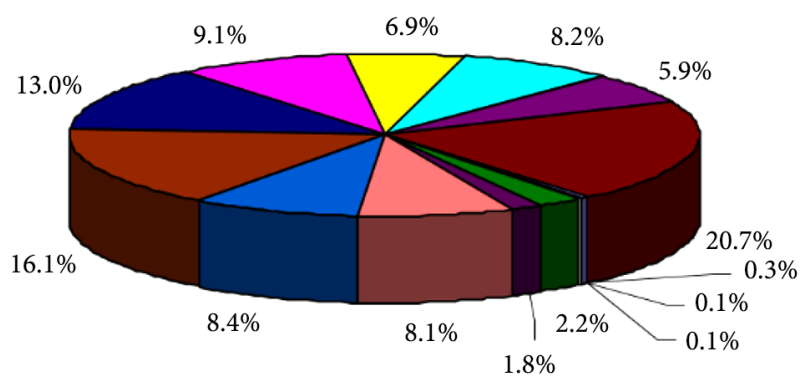

Figure 3. The share of the total area of agricultural land in Ukraine, which they occupy

economy, in fact, caused the significant negative changes in the structure of land use, which was one of the factors affecting the deterioration of the environment and soils state in particular. So, forest meliorative, agrotechnical, hydro meliorative measures, as well as land protection measures in most cases turned out to be unadapted to new land use conditions.

It should be noted that during the period of the land reform a significant number of problems in the sphere of land relations are recognized as exacerbated, and the state of the land resources of Ukraine is assessed as close to critical (Verkhovna Rada of Ukraine, 2011).

About $20 \%$ of Ukraine's territory is polluted, about $12 \%$ - flooded, about $57.5 \%$ are eroded land, the content of nutrients in soils is reduced, and annual losses of humus are 0.65 tons per 1 hectare (Verkhovna Rada of Ukraine, 2011). Over the past decades in Ukraine, the areas of alkalinized and saline soils have grown by 45.3 thousand hectares, washed-down lands - by 454.8 thousand ha, stony soils - by 8.3 thousand hectares (Shariy, 2010). 


\section{Results}

According to the data of the State Geocadastre, the area of agricultural land has been decreasing recently (Figure 4). It should be noted that this is mainly due to the area of natural fallow lands and hayfields (Figure 5).

Thus, it can be argued about the deterioration in the ratio of agricultural land with the invariably high value of the plowing of territory. At the same time, it should be noted that the opportunities, which are outlined by the legislation, which have developed in the process of economic relations reforming are not used. This concerns the follows: increase in the area of lands with natural landscapes (currently about 12.7 percent of the country's territory) (Verkhovna Rada of Ukraine, 2000); removing degraded arable land from agricultural use and land, which have lost the natural state and poses an increased risk to preserving the environment from industrial (mining, construction and other manufacturing industries) use; establishment of water protection zones and coastal protection belts around water bodies; increase the territory of forests, forest belts around agricultural lands, industrial and residential areas. In contrast, the systematic deforestation of protective forest stands, violation of the regime of land use within the boundaries of water protection zones and coastal protective bands is observed. This is typical for Ukraine as a whole, and for individual regions (Usakovsky et al., 2012).

The declared measures to reduce by 2020 year the arable land areas by an average of 5-10 percent by removing slopes with steepness of more than 3 degrees, lands of water protection zones, conservation of degraded, unproductive and technologically contaminated agricultural lands with subsequent reforestation in forest and forest-steppe zones and sodding in the steppe zone are not being realized (Verkhovna Rada of Ukraine, 2011). The scope of necessary works for reclamation and restoration of lands subjected to man-made impact also decreases (Zinchenko, 2012; Demidov, 2013).

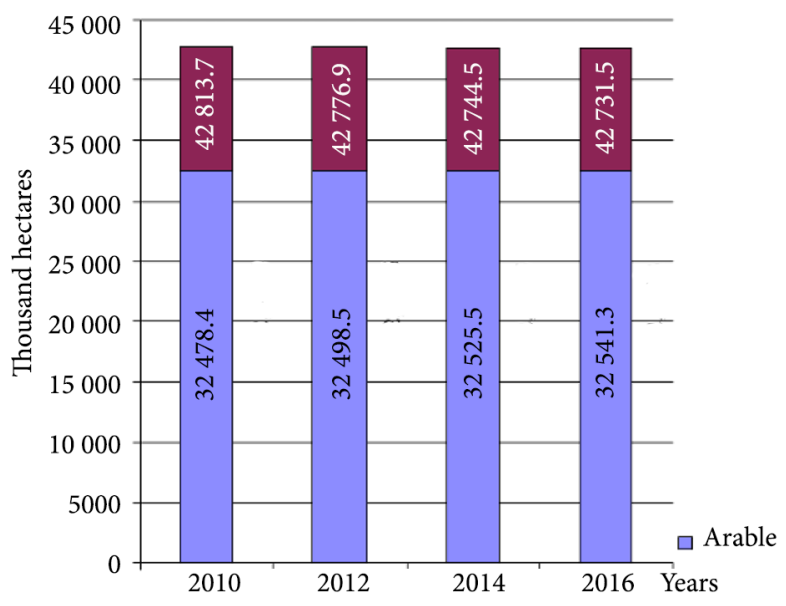

Figure 4 . The dynamics of changes in the areas of agricultural land and arable land in their composition in 2010-2016
In general, evaluating the change of land status in Ukraine, based on the targets, focused on indicators of sustainable development and the tasks of balanced environmental policy (Verkhovna Rada of Ukraine, 2011), it can be argued about the need for comprehensive measures to develop and implement technical solutions for the rationalization of land use and land protection.

These measures under modern conditions should be aimed at improving the ecological situation, creating environmentally friendly conditions for human life and health, ecologically balanced nature management, conservation of natural ecosystems and the formation of a national ecological network. In the context of this, priority tasks are:

- ensuring the rights of citizens to an ecologically safe environment for life and health;

- consideration the interests of the state or territorial communities when it is necessary to allocate land for the deployment of environmental and infrastructure facilities, defense facilities, etc.;

- regulation of economic activities with a view to preventing pollution, contamination and other types of land degradation, land use methods that cause loss and decline in soil fertility;

- prevention of manifestations and development of negative natural processes, such as flooding, landslides, water, and wind erosion;

- reclamation of lands exposed to the negative impact of both the economic activity and natural processes, conservation of degraded, low productivity and technologically contaminated lands, withdrawal from intensive use of lands having a slope with the steepness of more than 3 degrees, lands of water protection zones;

- formation of spatial and organizational conditions for effective economic activity.

The implementation of each of the above provisions calls for land redistribution with the aim of spatial optimization in the presence of many land users. At the same time, there is an acute need to implement measures for the use and protection of lands with a view to meeting the set tasks within the territories, which are subjected to significant anthropogenic load as a result of population

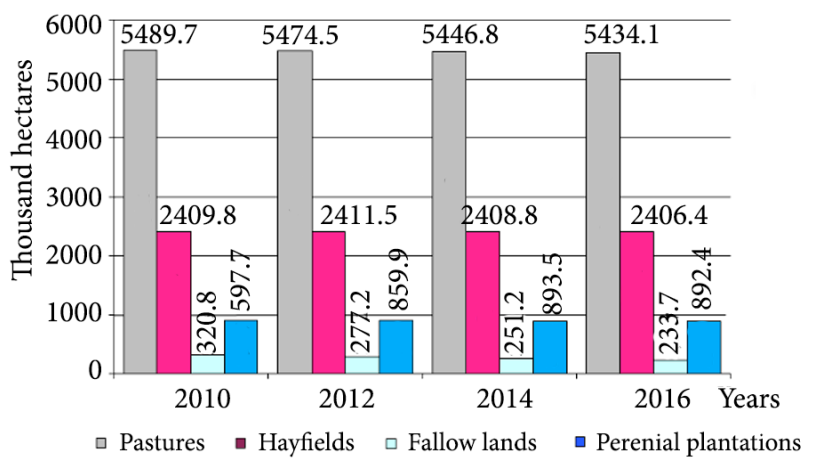

Figure 5. Dynamics of changes in the areas of pastures, hayfields, deposits, and perennial plantations 2010-2016 
accumulation and high intensity of land use. It should be noted that more than two-thirds of the existing population $(69.2 \%)$ live in cities since 2002 the share of the urban population has been steadily increasing (Ukrstat. org, 2017), there has been a positive balance of migration, including through the most proactive and economically active citizens (National Institute for Strategic Studies, 2012). Note that it is advisable to consider both cities and suburban areas. This is due to the interrelations and interdependence between them, since the use of land within the suburban zones is aimed at servicing and meeting the needs of the city, in particular in labor resources, food, as well as taking into account the formation of industrial cooperation and accommodation infrastructure, availability of recreation and, finally, the territorial reserves for the development of the city.

Within cities and suburban areas, there are lands for all categories of diverse functional purposes, as well as a wide range of issues for their use and protection. Currently, one of the main tasks is to establish the boundaries of settlements, because their absence limits the implementation of the powers of public authorities and local selfgovernment to regulate land relations, provokes conflicts on disposal of lands, making it impossible to accept the legitimate administrative decisions. Measures for the protection and use of land have no prospects for implementation in case of inconsistency of their belonging to one or another city/village council. At the same time, according to the data of the State Geocadastre, only 50 settlements have established boundaries among 29,772 settlements in Ukraine (Nizalov et al., 2016).

Another important issue is the allocation of land for facilities that represent a public need within the existing building. We are talking about coordinating with many landowners about the land redistribution for the purpose of transport infrastructure objects placing, the construction of protective hydraulic structures, the creation of urban parks, the construction of preschool educational institutions, recreational areas, stadiums, and cemeteries etc.

In the context of this problematic, it is advisable to consider the process of optimizing the urban space by regulating the density of construction, the use of house adjacent areas, the removal of production facilities outside the populated areas and justification of the territories use effectiveness, localization, and the return of illegally occupied land plots. No less important is an improvement of agricultural land use.

\section{Discussion}

Thus, according to the statistics, agricultural land accounts for an average of $72 \%$ of the total area and cities area of 35\% (Moskva zaglyanula pod zemlyu, 2008). Among the land plots of this category, spatial deficiencies are common: enclavement of plots, long-range lands, broken boundaries, erosion-hazardous location and the like. Within the cities, in the management of agricultural lands, the cases of actual loss of the land basic functional role - the means of production are often not taken into account. In addition, the formation of a transparent land market through the establishment of the land bank institution in its modern perspective and the use of past experience (Malashevsky \& Melnik, 2012) has not achieved the expected result in full.

The development of the basic principles of land consolidation and their practical implementation in European countries is characterized both by a long history of becoming in Western Europe (Sulonen \& Kotilainen, 2014), as well as the achievements of pilot projects of recent decades in some countries of Eastern Europe (Hartvigsen, 2014a; FAO, 2010).

The experience of East Germany is of special interest in land improvement, taking into account the socialist past. One of the tasks of land consolidation in Germany is to promote private farming.

Like most Western Europe countries and the postSoviet Union countries, Germany is faced with the problem of growing inequality of living conditions in urban and rural areas. Accordingly, there is a characteristic for Ukraine of the unwillingness of young people to engage in farming and live in rural areas, and as a result, the "aging" of the rural population, overpopulation of cities under depopulation of villages.

Also, among the shortcomings of land use peculiar to post-socialist countries, in East Germany, there is a significant fragmentation of land as a result of privatization (the average size of the site is 1.2 hectares), and if there is no accounting for the ownership rights to the large-scale farms land by cooperatives, the conflicts between ownership of land and its use need to be resolved (Hartvigsen, 2014b).

\section{Conclusions}

Based on the results of the survey of trends in modern land relations, the necessity of developing theoretical and practical approaches to the spatial ordering of land plots has been determined.

In today's conditions, with the rapid development of land relations in Ukraine, the issues of spatial ordering of land plots have not been fully studied. This direction requires more detailed study, improvement, and supplementation of the technical component of land monitoring and protection programs.

At first glance, the adoption of such a number of legislative initiatives should improve the state of land use in Ukraine. But in fact, there is a very different practical picture, chaotic building, unreasonable change in the purpose of the land, development of land management projects without unjustified technical solutions and other provisions led to a large number of negative economic, environmental and social changes. In this context, these problematic issues, in general, do not find their solution, because this requires study of the measures implementation specifics for the use and protection of land, stipulated by law. 
Positive foreign experience is necessary for the context of land consolidation for solving important tasks for the development of land management projects.

\section{Author contributions}

Mykola Malashevskyi conceived the study and was responsible for the design and development of the data analysis. Mariia Malanchuk was responsible for data collection and analysis. Olena Bugaienko and Alena Palamar were responsible for data interpretation.

\section{Disclosure statement}

Authors have no competing financial, professional, or personal interests from other parties.

\section{References}

Demidov, A. A. (2013). Ekoloho-ekonomichnyy analiz dynamiky ploshch promyslovo porushenykh, vidpratsovanykh ta rekultyvovanykh zemel $\mathrm{v}$ Ukrayini [Ecological and economic analysis of the dynamics of areas of industrially disturbed, worked and reclaimed lands in Ukraine], Balanced Nature Management, 4, 48-53.

Hartvigsen, M. (2014a). Land reform and land fragmentation in Central and Eastern Europe. Land Use Policy, 36, 330-341.

Hartvigsen, M. (2014b). Land mobility in a Central and Eastern European land consolidation context. Nordic Journal of Surveying and Real Estate Research, 10(1), 23-46.

FAO. (2010). Documentation of the International Symposium by FAO, GTZ, FIG, ARGE Landentwicklung and TU Munich Land Fragmentation and Land Consolidation in Central and Eastern European Countries: A gate towards sustainable rural development in the new millennium. https://www.oicrf.org/-/ international-fao-symposium-land-fragmentation-and-landconsolidation-in-central-and-eastern-european-countries-agate-towards-sustainable-rural-devel

National Institute for Strategic Studies. (2012). Shchodo problem rozvytku sotsialnoyi infrastruktury silskykh naselenykh punktiv: analitychna zapyska [On the problems of the development of the social infrastructure of rural settlements: an analytical note]. http://www.niss.gov.ua/articles/1132/

Nizalov, D., Ivinska, K., Kubakh, S., et al. (2016). Monitorynh zemelnykh vidnosyn $v$ Ukrayini 2014-2015 [Monitoring of land relations in Ukraine for 2014-2015]. Statistical yearbook. http://www.kse.org.ua/en/research-policy/land/governancemonitoring/yearbook-2014-2015/

Moskva zaglyanula pod zemlyu [Moscow looked underground]. (2008). Arkhitektura i stroitelstvo Moskvy, 4, 7-8. https://asm.rusk.ru/08/asm4/asm4_2.htm

Malashevsky, M. A., \& Melnik, L. V. (2012). Shchodo stvorennya zemel'nykh bankiv v Ukrayini [On the creation of land banks in Ukraine], Engineering Geodesy, 58, 67-70.

President of Ukraine. (1995). Pro poryadok payuvannya zemel, peredanykh u kolektyvnu vlasnist silskohospodars'kym pidpryyemstvam i orhanizatsiyam [On the procedure for dividing lands transferred to collective ownership of agricultural enterprises and organizations] dated 08.08.1995 No. 720/95. Decree of the President of Ukraine No. 720/95 of 08.08.1995. http://zakon5.rada.gov.ua/laws/show/720/95
Repin, K. (2016). Zemelna reforma: kriz pryzmu mynuloho i suchasnoho [Land reform: through the prism of the past and modern]. Land Management Bulletin, 1, 4-8.

Shariy, H. (2010). Derzhavne upravlinnya zemlyamy silskohospodarskoho pryznachannya: shcho zavazhaye vysokoefektyvno vykorystovuvaty ta nadiyno okhoronyaty yikh [State management of agricultural lands: what prevents them from being used efficiently and reliably protecting them]. Land surveyor, 5, 12-19.

Sulonen, K., \& Kotilainen, S. (2014). Lessor's status in land consolidation in Europe - Reports From Cyprus, Finland, France, Germany, the Netherlands, Latvia and Estonia. Baltic Journal of Real Estate Economics and Construction Management, 3(1), 56-71.

Ukrstat.org. (2017). Naselennya (1990-2016) [Population (19902016)]. State Statistical Service of Ukraine. https://ukrstat.org/ uk/operativ/operativ2007/ds/nas_rik/nas_u/nas_rik_u.html

Usakovsky, S. B., Malashevsky, M. A., \& Cuban, K. V. (2012). Suchasnyy stan ratsionalnoho vykorystannya ta okhorony silskohospodarskykh zemel Khmelnytskoyi oblasti [The current state of rational use and protection of agricultural land in the Khmelnytsky region]. Urban Planning and Territorial Planning, 43, 446-452.

Verkhovna Rada of the USSR. (1991). Pro zemelnu reformu [On Land Reform]: Decree dated 18.12.1990 No. 563-XII. Ukraine: Bulletin The Verkhovna Rada of Ukrainian SSR, No. 10, Art. 100.

Verkhovna Rada of Ukraine. (1992). Pro pryskorennya zemelnoyi reformy ta pryvatyzatsiyu zemli [On acceleration of land reform and privatization of land]: Resolution of the Supreme Council of Ukraine dated March 13, 1992, No. 2200-XII. Ukraine: Bulletin of the Verkhovna Rada of Ukraine, No. 5, Art. 355

Verkhovna Rada of Ukraine. (2000). Pro Zagal'noderzhavnu programu formuvannja nacional'noi ekologichnoi merezhi Ukraini na 2000-2015 roki [On the National Program for Creating the National Environmental Network of Ukraine for the Years 2000-2015]. http://zakon.rada.gov.ua/laws/show/en/1989-14

Verkhovna Rada of Ukraine. (2002). Zemel' nyy kodeks Ukrayiny [Land code of Ukraine]: Code of Ukraine dated 25.10.2001 No. 2768-III. Ukraine: Bulletin of the Verkhovna Rada of Ukraine, No. 3-4, Art. 27.

Verkhovna Rada of Ukraine. (2003). Pro porjadok vidilennja $v$ naturi (na miscevosti) zemel'nih diljanok vlasnikam zemel'nih chastok (paiv) [The Law of Ukraine On Land Management]. https://zakon.rada.gov.ua/go/899-15

Verkhovna Rada of Ukraine. (2011). Pro Osnovni zasadi (strategiju) derzhavnoi ekologichnoi politiki Ukraini na period do 2020 roku [About the main principles (strategy) of the state environmental policy of Ukraine for the period up to 2020]. http://zakon.rada.gov.ua/laws/file/2818-17

Verkhovna Rada of Ukraine. (2014). Zakony Ukrayiny "Pro fermers' ke hospodarstvo", "Pro osobyste selyanske hospodarstvo" [Laws of Ukraine "On Farming", "On Personal Peasant Economy”]: dated February 25, 2014. Official edition. (Series "Laws of Ukraine"). Parliamentary Publishing House.

Zinchenko, A. E. (2012). Retrospektyvnyy analiz ta otsinka suchasnoho stanu vykorystannya i okhorony zemel [Retrospective analysis and assessment of the current state of use and protection of lands]. Effective Economics, 7. http://www.economy.nayka.com.ua/?op=1\&z=1271 